\title{
No trade in Russian fossils?
}

SIR - The news report on "trade" in Russian fossils by Toni Feder and Alison Abbott (Nature 371, 729; 1994) drew a grim picture of the situation at the Museum of the Palaeontological Institute, Academy of Sciences, Moscow. As a palaeontologist concerned with governmental protection of fossils, I tried to assess the Russian situation during a recent study visit.

Feder and Abbott write that a fossil stolen from the museum was found in Germany but that "around 50 others are still missing" and "there is evidence that some researchers, faced with declining salaries, may be involved in the illegal export of fossil specimens from the scientific collections". They say that "the institute took little action to secure the return of the missing fossils". A responsible researcher mentioned by name who "was given the role of protecting Russia's palaeontological heritage" is quoted as excusing himself by having been "abroad for extended periods, and no-one else was interested". Allegedly, he later collected the rediscovered fossil in Germany and took it back to Moscow.

I learnt in Moscow that in fact 23 (not 50 ) fossils had disappeared, one of which was rediscovered; and that the researcher who was said to have collected the fossil in Germany had not in fact been there. In contrast to the situation implied by the news story, I found a remarkable devotion by the palaeontologists to their museum and fossils, a truly academic spirit.

In answer to my questions, I was told that the police had good reasons to suspect a former workman in the museum for the theft but he could not be prosecuted because of insufficient evidence. He was never a member of the staff and he no longer works on the museum premises.

The deputy director informs me that the statement describing an agreement with "a company called Kaminy Svetok" is true in so far as members of the Palaeontological Institute supervise the collectors of Kaminy Svetok and all scientifically valuable fossils have gone to the Palaeontological Museum. But the information that the institute "would also receive 80 per cent of any sales of fossils from its own collection" is derived from a clause that never had practical consequences.

Another statement that "a staff member at the academy's institute acknowledged the API's existence" is negated by the fact that such an "Applied Palaeontological Institute", called by Feder and Abbott "a vehicle for the sale of fossils", which may well have existed in the personal planning of one or more people, was never established at the institute.

The Palaeontological Institute and Museum in Moscow is exceptional in being a Russian state institution with a growing economy. This is not due to dubious transactions. But it is the consequence of, among other things, the devotion and hard work of its staff who create magnificent fossil exhibitions that travel abroad earning money for science and at the same time enable Russian palaeontologists to have fruitful contacts with Western colleagues. Wages are kept low in order to reserve finances for building up the scientific equipment, and the museum and its collections are cared for. Ella Hoch

GeologiskMuseum, Øster Voldgade 5-7,

1350 Copenhagen,

Denmark

SIR - The Palaeontological Institute of the Russian Academy of Sciences does not sell collections. It neither sold materials with the help of Kaminy Tsvetok, nor received shares of commercial activities of that company. The two-year agreement with Kaminy Tsvetok was not directed at participation in the company's benefits. The purpose was to supervise palaeontological collecting by the company and to select materials of scientific value to be donated by the company to the institute. During those two years, Kaminy Tsvetok donated more than 30 skulls and a dozen skeletons of Permian tetrapods (mostly reptiles). Staff researchers at the institute in turn identified the materials collected by the company.

The 1992 theft of 16 labyrinthodonts from the museum was a shock to everyone at the institute. It is not true that no one in the institute cared about the return of the fossils. We immediately got in touch with the Russian police and Interpol. The former director of the institute, Professor L. P. Tatarinov, published in SVP Bulletine a warning about the possibility that the stolen skulls might soon be available on the Western market. An international commission to track down the stolen skulls was established with the participation of the University of Bristol. Dr I. V. Novikov, the institute's deputy director, represents the institute's administration in the commission.

It is not clear what 50 missing skulls are referred to in the article. About a year after the museum theft, Dr M. A. Shishkin, head of the Amphibian Laboratory, reported 7 more specimens missing from the laboratory collections. No other skulls have been stolen.

The "Applied Palaeontology Institute" has never existed. However, in addition to Kaminy Tsvetok, many other private companies and individuals collect fossils in Russia. It is possible that some unscrupulous bone-dealers when selling fossils refer to them as "purchased" from the Palaeontological Institute's Museum to raise their "prestige".

On more than one occasion, we appealed to the Academy of Sciences Presidium and to various government bodies to make changes in legislation to harness the "wild" fossil market and private collecting. Unfortunately, our efforts met with only very limited success.

\section{A. Yu. Rozanov}

L. P. Tatarinov

Palaeontological Institute,

Russian Academy of Sciences,

Moscow,

Russia

- We erred in that it was Dr Rozanov, not Dr Novikov, who retrieved the Thoosuchus skull. The number of fossils stolen varied between 30 and 50 depending on sources. The receipt for the pareiasaur sale gives the Applied Palaeontology Institute (API) as the source, with the same address as the Palaeontological Institute (PI). When asked, members of the latter said that an enterprise such as the API had been planned but later retracted their comments

The agreement between the $\mathrm{PI}$ and Kaminy Svetok, of which we have a copy, specifies an 80 per cent fee to the PI for sales of their pieces. - Editor, Nature.

\section{CIESIN lives}

SIR - You report (Nature 374, 3; 1995) that the US House of Representatives' decision to cut $\$ 67$ million from NASA's budget would include closing the Consortium for International Earth Science Information Network (CIESIN) at Saginaw in Michigan.

However, the $\$ 27$ million cut in the NASA budget was obtained by rescinding the 1993 appropriation for a new CIESIN headquarters building. The network will continue to operate a very active programme from its existing facility on the campus of Saginaw Valley State University and with programme staff at sites worldwide. While the facility rescission is a setback to plans for expansion, it was not wholly unexpected.

President Bill Clinton's budget request recognizes the value of CIESIN by continuing a \$6-million annual operating budget in NASA's $\$ 1.3$ billion Mission to Planet Earth programme. Reports of our demise are grossly exaggerated.

\section{Roberta Balstad Mille}

Consortium for International Earth

Science Information Network, 2250 Pierce Road,

University Center,

Michigan 48710, USA

Letters submitted for Correspondence should be typed, double-spaced, on one side of the paper only. 